PSYCHOLOGIA ROZWOJOWA, $2019 *$ tom 24, nr 3, s. 105-106

doi:10.4467/20843879PR.19.026.11732

www.ejournals.eu/Psychologia-Rozwojowa

MAGDALENA KOSNO ID orcid.org/0000-0002-6304-4591

Instytut Psychologii, Uniwersytet Jagielloński, Kraków magdalena.kosno@uj.edu.pl

\title{
Sprawozdanie z 19. Europejskiej Konferencji Psychologii Rozwojowej, 29.08-1.09.2019, Ateny
}

W dniach 29.08-1.09.2019 roku w stolicy Grecji w otoczeniu starożytnych zabytków odbyła się 19. Europejska Konferencja Psychologii Rozwojowej organizowana przez Europejskie Towarzystwo Psychologii Rozwojowej oraz Uniwersytet Narodowy im. Kapodistriasa w Atenach. W konferencji wzięli udział psychologowie $\mathrm{z}$ wielu różnych krajów. Podczas czterech dni obrad odbyło się 5 wykładów plenarnych, 6 zamówionych sympozjów, 62 sympozja, 60 sesji referatów, 5 sesji plakatowych oraz wiele dodatkowych wydarzeń. Przed konferencją zostały również zorganizowane warsztaty poświęcone głównie zagadnieniom metodologii badań w psychologii rozwojowej oraz analizom statystycznym. Podczas konferencji wręczono także dwie nagrody przyznawane przez Europejskie Towarzystwo Psychologii Rozwojowej. Pierwszą nagrodę - The William Thierry Preyer Award - otrzymał prof. Wim Meeus (Utrecht University, Tilburg University) za oryginalny i wybitny wkład w badania nad rozwojem człowieka. Prof. Wim Messus prowadził eksperymentalne badania nad posłuszeństwem wobec autorytetów, a także liczne badania podłużne nad różnymi aspektami rozwoju w okresie adolescencji, takimi jak: osobowość, tożsamość, psychopatologia, relacje z rodzicami i rówieśnikami. Drugą nagrodę - The George Butterworth Award - przyznawaną młodym naukowcom, otrzymał Milica Nikolic z Uniwestytetu w Amsterdamie.

Głównym tematem konferencji był okres adolescencji, a także aplikacja badań psychologicznych w praktyce psychologicznej. Wygłoszone podczas konferencji wykłady plenarne odnosiły się do wskazanych przez organizato- rów głównych tematów konferencji. Rozwój w okresie adolescencji był tematem wykładu prof. Berny Güroğlu (Leiden University) zatytułowanego Dorastajacy mózg $w$ świecie przyjaciót $i$ wrogów. Prof. Güroğlu przedstawiała, jak funkcjonowanie adolescentów w kontekście społecznym, obejmującym procesy afektywne, regulacyjne, a także rozumienie innych i mentalizowanie, wiążą się z modulowaniem aktywności neuronalnej w obszarach mózgu zaangażowanych w powyższe procesy. Poszczególne obszary mózgu zaangażowane w procesy afektywne, regulacyjne oraz związane z mentalizowaniem mają zróżnicowane trajektorie rozwojowe. Podkorowe regiony mózgu uczestniczące w procesach afektywnych wykazują zwiększoną aktywację we wczesnym okresie dojrzewania. Z kolei regiony przedczołowe i skroniowe biorace udział w procesach regulacyjnych i mentalizacyjnych wykazują wzrost aktywacji w późnym okresie dojrzewania. Jak wykazała prof. Güroğlu, kontekst społeczny, a zwłaszcza relacje rówieśnicze, może wyraźnie modulować wzorce aktywacji neuronów w poszczególnych regionach mózgu związanych z danymi procesami. Również prof. Koen Luyckx (Katholieke Universiteit Leuven) w swoim wykładzie Tożsamość $w$ okresie dojrzewania $i$ wczesnej dorosłości: perspektywa rozwojowa $w$ klinicznym kontekście prezentował wyniki badań dotyczących okresu adolescencji, ukazujących związek rozwoju tożsamości badanej w nurcie neoeriksonowskim z występowaniem $\mathrm{w}$ okresie adolescencji zaburzeń psychicznych, takich jak zaburzenia odżywiania, a także z występowaniem samobójstw oraz samookaleczeń. 
Drugim głównym tematem konferencji było zastosowanie badań nad rozwojem w praktyce psychologicznej. Prof. Louise Arseneault (King's College London) w wykładzie zatytułowanym Przeciwstawianie się zastraszaniu: społeczne i indywidualne koszty bycia prześladowanym $w$ dzieciństwie prezentowała badania ukazujące skuteczność profilaktycznych programów, które mogłyby przeciwdziałać konsekwencjom doświadczania przemocy w dzieciństwie. Temat przemocy w szkole oraz cyberprzemocy pojawiał się na konferencji na wielu różnych sympozjach oraz w wystąpieniach, w których prezentowano różne, stosowane w szkołach programy przeciwdziałające negatywnym skutkom przemocy między uczniami.

Również w wykładzie plenarnym wygłoszonym przez prof. Tinę Malti (University of Toronto) pod tytułem Wykorzystanie nauki o rozwoju społeczno-emocjonalnym dziecka $w$ praktyce został podjęty temat wykorzystania badań nad rozwojem w praktyce psychologicznej. Zdaniem prof. Malti programy wspierające takie aspekty rozwoju społeczno-emocjonalnego, jak troska o innych, samoświadomość stanów emocjonalnych oraz regulacja emocji w znacznym stopniu wpływają na poprawę funkcjonowania dzieci doświadczających różnych trudności.

Wiele specjalnych sympozjów koncentrowało się również na metodologii badań w psychologii rozwojowej, a niektóre $z$ nich poświęcono tematom związanym z Big Data. Na sympozjum przygotowanym przez prof. Sabine Walper (German Youth Institute and Ludwig-Maximilians-University) podkreślano znaczenie Big Data w badaniach z zakresu psychologii rozwojowej.
Na przykładzie zakrojonych na szeroką skalę badań podłużnych, które zapewniają zainteresowanym badaczom szeroką bazę danych typu open source, a także badań online prowadzonych w portalach społecznościowych oraz za pomocą aplikacji mobilnych, ilustrowano trudności oraz zalety analiz rozwojowych dużych zbiorów danych. Temat analiz statystycznych w badaniach rozwojowych podjęła również prof. Ellen Hamaker (Utrecht University) w swoim wykładzie $O$ znaczeniu oddzielenia dynamiki wewnatrzosobniczej od różnic międzyosobowych w procesach psychologicznych. Prof. Hamaker podkreślała znaczenie badań podłużnych, które umożliwiają rozdzielenie analiz międzyosobowych (between-person) od analiz wewnattrzosobowych (within-person). Rozdzielenie tych dwóch analiz umożliwia nam wnioskowanie o stabilności i ciagłości obserwowanych zmian mierzonych zmiennych w czasie.

Poza głównymi zagadnieniami na konferencji prezentowano także zagadnienia dotyczące wielu różnych dziedzin badań w psychologii rozwojowej, dotyczących rozwoju od okresu prenatalnego do starości. Mimo to perspektywa life-span była na konferencji przedstawiana w mniejszym zakresie, a znaczna część sympozjów i sesji dotyczyła badań okresu dzieciństwa i adolescencji.

19. Europejska Konferencja Psychologii Rozwojowej stanowiła okazję do wymiany myśli naukowej i refleksji nad różnymi, ważnymi sferami rozwoju człowieka. Kolejna, 20. już konferencja pod auspicjami Europejskiego Towarzystwa Psychologii Rozwojowej odbędzie się w dniach 1-5 września 2021 roku w Sankt Petersburgu w Rosji. 